\author{
Iwona Wrześniak \\ Magister, zastępca notarialny \\ Doktorantka na Wydziale \\ Prawa, Administracji i Ekonomii \\ Uniwersytetu Wrocławskiego \\ iwona_wrz@wp.pl
}

DOI: 10.35117/A_ENG_19_08_04

\title{
The expropriation of ownership for building a public road - procedure - compensation
}

\begin{abstract}
The procedure for expropriation of the property is based on the removal of the ownership right of the current owner to benefit the overall public which is usually the construction of public utilities, e.g. roads. The justification for expropriation is based on the permission to carry out a road investment, which has legal-property (material) effects - the power of the law itself transfers ownership to a public entity: the State or a local government unit, therefore, it is the most extensive interference in ownership relations. The Act of 10 April 2003 dealing with special rules for the preparation and implementation of investments of public roads introduces a simplified, one-step expropriation procedure aimed at accelerating and streamlining the implementation of road investments in Poland. Expropriation is possible only when just compensation is paid. In order to determine the amount of compensation, it is necessary to assess the market value of a given (concreto) property. The compensation entitlement for the withdrawal of the property right does not become time-barred, thus, the party to expropriation proceedings may demand it at any time. The compensation function is implemented by granting the holder usually a cash payment for the expropriation of real estate on which the road will be built.
\end{abstract}

Keywords: Expropriation of real estate; Compensation; Special purpose Road Act

he economic and spatial development of agglomeration centers in Poland creates the need for investments, in particular in the construction of public roads, which will improve communication and connectivity between cities or within them. The legal measure to achieve this goal is undoubtedly the possibility of expropriation of the land property for public road use. Protection of property rights was guaranteed in the Constitution of the Republic of Poland [14], but already in its Article 21 paragraph 2, which provides for the possibility of expropriation [3] when it is carried out for public purposes and for just compensation. In addition, the legislator decided that property may be restricted only by statute and only to the extent that this restriction does not affect the essence of the right to property [13]. The basic legal act in which the procedure and procedure for the expropriation of real estate was regulated is the Act of 21 August 1997 on real estate management [22]. However, the legislator provided for in the Act of 10 April 2003 on specific principles for the preparation and implementation of investments in public roads, the so-called Road Act [19], special provisions regulating the terms and conditions for the preparation of road investments, including in particular the expropriation of real estate for public roads, and also specified the premises for the purchase of real estate for this purpose by road managers and competent authorities in these matters. The main goal of the introduction of the abovementioned act was to accelerate the construction of roads throughout the country, and thus to optimize the existing road network by preparing the investment in the most effective and comprehensive 
way [15]. In the explanatory memorandum to the draft Act on special rules for the preparation and implementation of investments in public roads, we can read "Accelerating the development of the national road network is a condition for catching up in this respect between Poland and most European countries and the basis for long-term economic and civilization development of the country" [10].

Unfortunately, this process is necessarily accompanied by the depletion or deprivation of ownership of the property (in particular a plot of land or part of it), which the competent authority decides in the content of the permit to implement a road investment [6].

\section{Procedure for the expropriation of land ownership rights}

Special purpose Road Act, in particular after legislative changes introduced by the 2006 and 2008 amendments [21], basically creates a one-step procedure for purchasing land property for a public road, as a result of which a decision is issued to authorize the implementation of a road investment, ending the proceedings in case [30]. It is comprehensive because it contains diverse material and legal elements and replaces a number of independent administrative decisions, regulated in separate provisions, such as:

- decision on determining the location of a public purpose investment - road construction (Article 50 (1) of the Act of 27 March 2003 on spatial planning and development [24]), in turn, Art. 51 paragraph 1 of the said Act clarifies that the bodies competent to issue a decision on determining the location of public purpose investments are in relation to a) public purpose investments of national and provincial significance - the head of a commune, mayor or city president in consultation with the province marshal; b) public purpose investments of poviat and commune significance - the head of a commune, mayor or city president; c) public purpose investments in closed areas - governor (voivode),

- decision on approval of the division of real estate (Art. 92 et seq. of the Act of 21 August 1997 on real estate management), which, according to Art. 96 section 1. the indicated act is issued by the head of the commune, mayor or city president,

- decision on approval of a construction project and granting a building permit (Article 28 of the Act of 7 July 1994 Construction Law [25]) which is issued by the competent authority of architectural and construction administration, i.e. at the poviat level staroste, at the voivodship level - and at the central level, the Chief Inspector of Building Supervision (Article 80 paragraph 1 of the Act of 7 July 1994 Construction Law).

The changes introduced by the abovementioned amendments from 2006 and 2008 were aimed at reducing the degree of bureaucratism, and thus the acceleration and improvement of the investment procedure in the construction of public roads, one of the significant amendments to the amendment was the introduction of the decision to authorize the implementation of the road investment, as well as the identification of new rules on the expropriation of real estate and awarding compensation for real estate taken over roads.

In addition, it should be noted that in accordance with art. 11 and paragraph 2 of the Act on special rules for the preparation and implementation of investments in the field of public roads, the legislator explicitly excluded the application of the provisions of the Act on spatial planning and development and the Act of 9 October 2015 on revitalization [1] in matters relating to the permission to implement a road investment, so the question arises whether can the permit be issued without the provisions of the local spatial development plan or even in contradiction with its provisions? M. Gdesz takes the position that if the current local development plan provides for a public road, then based on this plan one should apply for a decision on the permit for the investment [12]. Quite different views are represented by 
M. Wolanin because he believes that the cited provision resolutely and unequivocally determines the lack of the need to bind the investor, as well as the authority issuing the decision itself the arrangements of the local plan [26].

The most important differences in purchasing real estate for the construction of a public road should be included:

- determination by the legislator of a substantive, spontaneous premise for the expropriation of land property, which is its purpose of acquisition, which is undoubtedly the construction of a public road,

- introduction of differentiation of the mode of purchasing real estate for the purpose of road investment depending on which entity is entitled to ownership [28].

The comments made above lead to establishing a group of entities for the benefit of which expropriation may be understood as the furthest-reaching interference with the right of ownership, leading to the acquisition of real estate. According to the content of Art. 12 paragraph 4 point 1) of the special purpose Road Act - real estate owned by entities other than the State Treasury becomes the property of the State Treasury with respect to the category of national roads. On the other hand, real estate owned by entities other than the State Treasury becomes the property of local government units - commune, poviat, province - in relation to commune, poviat and province roads respectively (Article 12 (4) (2) of the Road Act). In turn, for the third category of entities, the legislator introduced a special mode of purchasing real estate based on different rules. Thus, in relation to real estate owned by the Treasury or local government units allocated for road lanes:

- if they were commissioned for perpetual usufruct, their usufruct expires as soon as the decision to authorize the road investment is finalized (Article $12(4 \mathrm{~d})$ of the special purpose Road Act),

- if they were transferred to a permanent management government, the governor or staroste issues a decision on the expiry of the permanent management government, except for the situation where a permanent management government is established for the competent road manager or road government - a local government organizational unit (Article 19 (1) of the special purpose Road Act),

- if they have been leased, rented or lent, the competent road administrator terminates the lease, rental or lending contracts with immediate effect, but the party who suffered losses is entitled to compensation (Article 19 (2) of the special purpose Road Act).

The expropriation of real estate, and thus the transfer of ownership to authorized entities, takes place from the "right of the law" on the date on which the decision to authorize the implementation of the road investment became final. Therefore, this decision is declaratory in nature as regards the effects on the right of law [29]. It constitutes the basis for making an entry in the land and mortgage register and updating data on the owners in the real estate cadastre.

The property, which was acquired by the State Treasury or local government unit as a result of expropriation, the current owner may use until the announcement of construction works by the investor. It should also be noted that in the provisions of the commented road law, no regulation can be found that would indicate the time-limited nature of the permit validity for the implementation of a road investment. One can infer from this that it was a deliberate legislative procedure by the legislator that did not want to suspend the implementation of road investments and the length of proceedings. Otherwise, he would post a similar regulation, modeled on the provision of Art. 37 paragraph 1 of the Construction Law, pursuant to which the building permit decision expires as a result of not starting construction works within 3 years of the date on which the decision became final, or 
construction was interrupted for more than 3 years. The validity of the decision has been expressly limited by the legislator to a 3-year period.

Another act of the legislator aimed at preventing the long-term implementation of the investment and construction process, which would pose a threat to the public interest, in particular, those related to the lack of the expected development of road infrastructure, was to introduce a deadline binding for the public administration body to settle the administrative matter. The governor - in relation to national and provincial roads, and the staroste - in relation to poviat and commune roads is obliged to issue a decision on permission to carry out a road investment within 90 days from the day of submitting the application for a permit. If the competent authority does not issue a decision within such a time limit set by the legislator, it is exposed to a financial penalty in the form of a fine of PLN 500 for each day of delay (Article 11h (1) of the special purpose Road Act). Therefore, this deadline is not of an instructional nature, but binding on the authority issuing the decision terminating the proceedings at first instance (in contrast to the general deadlines set out in Article 35 of the Act of 14 June 1960 - Code of Administrative Procedure [20] (hereinafter referred to as Code of Administrative Procedure)). The legislator also decides who has the legitimacy to submit an application for permission to implement a road investment - he is the administrator of a public road - in practice it can usually be the General Director of National Roads and Motorways, head of the commune, mayor, city president, poviat government, province government, or a special purpose road company.

The party has the right to appeal against the decision to authorize a road investment within 14 days from the date of delivery of its notification of the decision, which should be addressed to a higher level authority which has 30 days to consider the appeal. On the other hand, the administrative court examines the complaint within two months of its submission (Article 11g (1) of the special purpose Road Act)[31].

\section{Compensation for expropriated land property}

The last key element completing the procedure of expropriation of real estate under the special purpose Road Act is obtaining a decision determining the amount of compensation for real estate, which in essence is a separate administrative decision (it is not an integral part of the decision to authorize a road investment). Competence to issue it is held by the authority which is competent in the procedure for issuing a permit for the implementation of a road investment within 30 days from the date on which the decision to authorize the investment became final (Article 12 (4a) and (4b) of the special purpose Road Act). The decision issuing authority determines the last resort when the decision cannot be appealed against in the administrative course of the instance or a request for reconsideration of the case (Article $16 \S$ 1 of the Code of Civil Procedure) [34]. The legislator has differently set the deadline for issuing a compensation decision in the event that the decision to authorize the road investment has been immediately enforceable, then the compensation decision is issued within 60 days of being immediately enforceable (Article $12(4 \mathrm{~g})$ of the special purpose Road Act). It should be noted that compensation for the takeover of real estate under the road takes place only when it is intended for a public road, but there is no legal basis for payment of compensation for the expropriation of real estate that will be used as internal roads [35].

Special purpose Road Act in the content of Art. 12 paragraph 4f defines the circle of persons entitled to receive compensation for expropriation of real estate for the construction of a public road, these are property owners, perpetual usufructuaries of real estate, entities with limited property rights, e.g. a mortgage, pledge or cooperative ownership right to premises. Therefore, this category of entities includes not only physical persons but also legal persons and organizational units without legal personality. However, the legislator specifies that these are "current" owners, this is a fundamental issue in the event of changes in 
ownership, e.g. through the sale of the property in question, then it seems that the competent authority has the obligation to determine which entity has the right to ownership of the property on the day on which the decision to authorize the road investment became final. On this day, the property right is acquired by the State Treasury, province, poviat or commune. The jurisprudence expressed the position that a change of the person entitled to compensation may occur not only as a result of the transfer of rights to real estate but also as a result of the assignment of rights to compensation itself, but due to the administrative law nature of compensation this is a disputable view [32]. The death of a person who is entitled to compensation does not lapse the claim for its payment [33], as it is a property right which is subject to inheritance on general principles (Article 922 of the Act of 23 April 1964 - Civil Code [23]).

The provisions of the special purpose Road Act do not specify the form of implementation of claims for compensation for expropriated property. Therefore, it should be assumed that any form permitted by law is possible. The most widely used form of compensation for repossessed property in practice is cash, the exception is the receipt of a replacement property. Based on the provisions of the commented Act, it is most important that the loss of property be compensated regardless of the form adopted. However, used in Art. 12 paragraph 5 of the special purpose Road Act by the legislator, the phrase "payment of compensation" suggests the preferred form of the cash benefit.

Noteworthy is the special form of compensation provided for by the legislator in Art. 13 section 3 of the special purpose Road Act, from which it follows that if only part of the property is taken over for the needs of the road investment, and the remaining part is not suitable for its current use, the relevant road manager is obliged to purchase, at the request of the owner or perpetual usufructuary of the property, on behalf of and for the benefit of the Treasury or local government unit of this part of the property (the so-called residual). It seems that the justification for introducing this form of compensation results from the fact that getting rid of the useless part of the property - in exchange for payment of its equivalent, may in certain cases be a more beneficial solution for the party.

\section{Determining the amount of compensation}

Expropriation of property rights to meet the constitutional requirements set out in Art. 21 paragraph 2 of the Constitution of the Republic of Poland should be made with the payment of "just compensation" to the current owner of the property. The case-law has established itself on the view that the legal protection of an individual manifested in the granting of compensation for the loss of subjective rights finds its source not only in the content of Art. 21 paragraph 2 of the Constitution of the Republic of Poland, but also in the principle of a democratic state ruled by law, fundamental for our legal order, expressed in Art. 2 of the Constitution of the Republic of Poland [9].

It should be emphasized that the act of international law - European Convention for the Protection of Human Rights and Fundamental Freedoms of November 4, 1950 [11] also provides for the right to protection and respect for property, which is expressed in the content of Art. 1 of Additional Protocol No. 1 to the European Convention for the Protection of Human Rights and Fundamental Freedoms of November 4, 1950. The provisions of the Convention, however, allow the deprivation of property rights under specific conditions. Expropriation must be carried out in the public (general) interest, in addition to statutory conditions and in accordance with the basic principles of international law. No state authority may arbitrarily restrict or deprive entities of their ownership rights. The basic requirement that must be observed for a breach of property rights to be considered legal and admissible is the right to compensation. In the opinion of the European Court of Human Rights, compensation 
does not mean full compensation, but it is sufficient for it to remain rational to the actual value of the property in question and even not to be grossly unfair [2].

The legal term "just compensation" under constitutional provisions is a vague term [37], it is defined in case-law as compensation enabling the restoration of things (including real estate) taken over by the State Treasury or a local government unit following an expropriation. In particular, this means that the amount of compensation determined should correspond to the market value of the expropriated property or property right. Therefore, for a claim to be qualified as fair it must be based on the principle of equivalence of benefits [36]. In the doctrine of administrative and constitutional law, there is a view that the concept of just compensation should only be equated with compensation for losses suffered - damnum emergens, without omitting lost benefits - lucrum cessans [27].

The legislator has clearly determined that the amount of compensation and its payment are determined on the basis of the provisions of the Real Estate Management Act (Article 12 (5) of the special purpose Road Act), however, taking into account the regulations provided for by the special purpose Road Act (in particular Article 18), which constitute provisions lex specialis with respect to the provisions of the Real Estate Management Act. In accordance with Art. 132 section 1a of the Real Estate Management Act, payment of compensation should be made once within 14 days from the date on which the decision determining the amount of compensation became final. It should be noted here that as a result of an agreement between a person entitled to compensation for the expropriation of property and an authority obliged to grant it, Art. 132 section 4 of the Real Estate Management Act, it is possible to determine another way of paying compensation. In particular, this means the opportunity to agree with the public administration body a different date for payment of compensation than the one indicated above [7].

The amount of compensation determined is subject to indexation as on the day of its payment (Article 132 (5) of the Real Estate Management Act). The institution of valorisation aims to ensure the real amount of compensation as at the date of its payment, as well as to protect the person entitled to compensation in the event of a decrease in the value of money since the decision to authorize the road investment, and thus to prevent the loss of value of compensation [8]. Besides, the possibility of indexation of compensation does not exclude the right of a party to compensation proceedings to demand interest for delay or delay in its payment (Article 132 (2) of the Real Estate Management Act). Interest will be charged for any delay in payment of compensation, regardless of the reasons for the delay, as well as whether the party has suffered any damage due to delay [4]. It should be mentioned that if a compensation decision is revoked or overturned, a person who has received a financial benefit as compensation will be obliged to return it (Article 132 (3) of the Real Estate Management Act).

Often, the existing use of the land covered by the decision to authorize the implementation of a road investment will be very difficult or even impossible. Purchase of real estate - as a special form of implementation of a claim for damages should be assessed as a just and reasonable legal solution. Then, the obligation to submit an appropriate application for the purchase of part of the property, as well as to demonstrate that there is a premise that the property cannot be used in a current manner, lies with the owner of the property. This procedure leads to a situation in which the competent public administration body is obliged to buy things that are not necessary for the proper construction of a public road. However, the authority does it due to the protection of wider social interest, thus fulfilling the compensation function.

The basis for determining the amount of compensation due to the property owner is the market value of the property (Article 134 (1) of the Real Estate Management Act). The value in question is determined according to the state of the property on the day of issuing the 
decision authorizing the implementation of the road investment (in the first instance) and according to its value as at the date on which the amount of compensation is determined. The adoption of such a method of determining the amount of compensation also meets the requirements of the principles of proportionality and social justice. The concept of the market value of real estate has been defined on the basis of the provisions of the Real Estate Management Act (Article 151 (1)), specifying that the market value of real estate is the most probable price it can obtain on the market, determined to take into account transaction prices with the following assumptions: 1) the parties to the contract were independent of each other, did not act in a forced situation and had a firm intention to conclude the contract, 2) the time necessary to display the property on the market and to negotiate the terms of the contract expired.

The amount of compensation is determined after the certified property valuer draws up an appraisal report [5], taking into account the facts of the property on the date of the decision and its value at the time the compensation is paid. The obligation to draw up this estimate, as well as the related costs, is borne by the body issuing the compensation decision. The question arises about the validity of the valuation made by the certified property valuer and its possible update. According to the content of Art. 156 section 3 of the Real Estate Management Act, the appraisal report may be used for the purpose for which it was drawn up for 12 months from the date of its preparation unless there have been changes in legal conditions or significant changes in factors. However, after the expiry of the period referred to above, it is necessary to confirm its validity by a certified property valuer. When determining the amount of compensation, an account is taken, in particular, of the type, location, manner of use, purpose, condition of real estate and currently evolving real estate prices - transaction prices (Article 134 (2) of the Real Estate Management Act). On the other hand, if, due to the type of real estate, its market value cannot be determined, because this type of real estate is not traded, its replacement value is determined (Article 135 (1) of the Real Estate Management Act), but in practice, it is extremely rare [17].

It should be emphasized that compensation should relate not only to the determination of the value of the property itself but also to buildings and other building structures erected on the property (including trees and other plants located on its territory). Based on Article. 18 clause 1a and 1c of the Road Act, the compensation due to the property owner is reduced by an amount equal to the value of the limited property rights encumbered by the property in question. At the same time, it should be emphasized that the value of all damages granted for limited property rights to a specific property cannot exceed the total value of the property.

In the jurisprudence, you can find a position that allows you to deduct the right to life imprisonment on the property, even though this right is not included in the category of limited property rights. Undoubtedly, the advisable interpretation supports the adoption of such a solution, as well as the appropriate application provided for by the legislator when charging life imprisonment with provisions on limited property rights (Article 910 of the Civil Code) [18]. It is worth noting that it is always possible to question the amount of compensation awarded by filing an appeal against the decision determining the amount of compensation for the acquisition of real estate. However, the controversial issue is the admissibility of waiving damages due to the expropriated party. Both the provisions of the road law, the Real Estate Management Act and broadly understood administrative law do not provide for such permission [38].

Specific provisions affecting the amount of compensation for expropriation of real estate are Art. 18 clause 1e and Art. 18 clause 1f road specification. These regulations create, on the part of the owner or perpetual usufructuary, the right to obtain additional compensation in the form of $5 \%$ of the value of the property or perpetual usufruct, if he issues the property within the period specified in Art. 18 clause 1e, and besides the right to receive additional 
compensation for deprivation of the property on which the apartment building was located or a dwelling was separated - then the amount of compensation due to the current owner is increased by a lump sum of PLN 10,000. It seems that ratio legis of the provision by the legislator of the provision of Art. 18 clause 1e of the road act was the acceleration and improvement of the investment procedure related to the construction of a public road by encouraging the owners to leave the real estate covered by the decision on the permit for the implementation of the road investment faster (without delay). In turn, granting additional, special compensation, referred to in Art. 18 clause 1f of the road law due to the loss of ownership of a property built-up with a residential building, implements the principles of social justice, as it provides ad hoc assistance in providing basic housing needs and living conditions for existing owners [16].

Considering the above considerations, it should be stated that the adopted legal constructions and the regulations presented above regarding the determination and estimation of the amount of compensation are based on a comprehensive analysis of the actual state of the property being the subject of expropriation by the authority issuing the compensation decision, and also show the correct protection of the interests of the entity most clearly visible in ensuring the right to just compensation for expropriation. However, any deficiencies or irregularities in the findings will result in the need to seek the protection of the individual interest in the appeal procedure.

\section{Summary}

The property expropriation procedure results in the removal of ownership of the current owner due to public interest - construction of a public road. The expropriation is made through a decision authorizing the implementation of a road investment, which has legal effects - under the law itself, it transfers ownership to a public entity: the State Treasury or a local government unit, which is why it is the most far-reaching interference in ownership relations. The Act of 10 April 2003 on special rules for the preparation and implementation of investments in public roads introduces a simplified, one-step expropriation path, displacing the basic regulations for expropriation institutions contained in the Act of 21 August 1997 on real estate management. Expropriation of property rights to meet the constitutional requirements set out in Art. 21 paragraph 2 of the Polish Constitution should be made with the payment of "just compensation." The amount of compensation is determined according to the state of the property on the day of issuing the decision to authorize the road investment and its value as of the date on which the amount of compensation is determined. An indispensable document used to estimate the value of a real estate is an opinion prepared by a certified property valuer in the form of an appraisal report. The basis for determining the amount of compensation is the market value of the property. The amount of compensation determined in the decision is subject to indexation as on the day of its payment. Valorization is carried out by the body, person or organizational unit obliged to pay compensation. Compensation for revoking property ownership rights is not time-barred, therefore a party to expropriation proceedings may demand it at any time. The compensation function is implemented by granting the beneficiary, most often cash benefits for the expropriation of the property on which the road intentions are to be implemented.

The legal regulations adopted by the legislator in the area of expropriation and compensation procedure allow a person injured as a result of expropriation of real estate to fully realize his economic interest, providing legal tools for its effective protection, e.g. by providing the party with the opportunity to appeal against the decision to authorize a road investment, a decision determining the amount of compensation for real estate, providing insight into the documentation gathered in the matter, appraisal report, as well as ensuring the possibility of making notes, transcripts or photos from it. The owner of the expropriated 
property may question the correctness of the appraisal presented by the authority, in which case he has the right to report the charges. If the explanations provided by the expert are not sufficient for the party to the proceedings, he may request the authority to conduct an administrative hearing involving the expert. Besides, the owner of the expropriated property may, on his request, request that the certified property valuers elected by him assess the value of the property or apply to the professional organization of property valuers to assess the correctness of the appraisal prepared by the current certified property valuer.

\section{Source materials}

[1] [Ustawa z dnia 9 października 2015 r. o rewitalizacji (t.j. Dz. U. z 2017 r. poz. 1023 ze zm.).

[2] Andrzejczuk R., Ochrona prawa własności w Europejskiej Konwencji Praw Człowieka i Podstawowych Wolności, Roczniki nauk prawnych, tom XV, numer $1-2005$.

[3] Art. 112 ust. 2 i ust. 3 ustawy z dnia 21 sierpnia 1997 r. o gospodarce nieruchomościami (t.j. Dz. U. z 2018 r. poz. 121 ze zm.) definiuje pojęcie „wywłaszczenia” nieruchomości, precyzując iż polega ono na ,pozbawieniu albo ograniczeniu, $w$ drodze decyzji, prawa wtasności, prawa użytkowania wieczystego lub innego prawa rzeczowego na nieruchomości, tylko wówczas, gdy cele publiczne nie moga być zrealizowane $w$ inny sposób niż przez pozbawienie albo ograniczenie praw do nieruchomości, a prawa te nie moga być nabyte w drodze umowy".

[4] Bieniek G. (red.), Komentarz do kodeksu cywilnego. Księga trzecia. Zobowiązania, t. I, LexisNexis, 2005, s. 233.

[5] Bieniek G., Wywłaszczenie nieruchomości, W: Bieniek G, Rudnicki S. Nieruchomości. Problematyka prawna, LexisNexis,2013, s. 1093 - 1095.

[6] Błaś A., Prawne formy działania administracji publicznej w: Boć J. (red.), Prawo administracyjne. Kolonia Limited, 2007, s. 317 -332.

[7] Bończak - Kucharczyk E., Ustawa o gospodarce nieruchomościami. Komentarz aktualizowany, Wolters Kluwer, 2017, s. 467.

[8] Czechowski P. (red.), Ustawa o gospodarce nieruchomościami. Komentarz, Wolters Kluwer, 2015, s. 635-638.

[9] Drab M. K., Ochrona właściciela wywłaszczanej nieruchomości, jako przejaw realizacji zasady demokratycznego państwa prawnego. W: Filipek J. (red.) Jednostka w demokratycznym państwie prawa, Wyższa Szkoła Administracji 2003, s. 180.

[10] Druk sejmowy $\mathrm{nr} 858 \mathrm{z}$ dnia 30 sierpnia 2002 r., IV kadencja Sejmu (orka.sejm.gov.pl/Druki4ka.nsf/wgdruku/858/\$file/858.pdf, 15.06.2018 r.).

[11] Dz.U. z 1993 r., Nr 61, poz. 284.

[12] Gdesz M., Zmiana ustawy o szczególnych zasadach przygotowania inwestycji w zakresie dróg publicznych, Polskie Drogi, 2008 r., nr 10, s. 63.

[13] Jarosz-Żukowska S., Spory wokół pojęcia wywłaszczenie w ujęciu Konstytucji Rzeczypospolitej Polskiej, Państwo i Prawo, 2001 r., nr 1, s. 16-31.

[14] Konstytucja Rzeczypospolitej Polskiej z dnia 2 kwietnia 1997 r. (Dz. U. z 1997 r. Nr 78, poz. 483 ze zm.).

[15] Kozłowska M., Specustawa drogowa jako narzędzie prawne usprawniające realizację inwestycji drogowych w Polsce, Przegląd Komunikacyjny, 2/2018, s. 28-32.

[16] Peljan M., Ochrona interesu indywidualnego w postępowaniu administracyjnym dotyczącym lokalizacji i budowy dróg publicznych - na podstawie przepisów tzw. specustawy drogowej (rozprawa doktorska), Uniwersytet im. Adama Mickiewicza w Poznaniu Wydział Prawa i Administracji, 2014 r.

[17] Strzelczyk R., Prawo nieruchomości, C. H. Beck, 2015, s. 541-542. 
[18] Uchwała Sądu Najwyższego z dnia 2 kwietnia 2003 r., sygn. akt.: III RN 55/02, System Informacji Prawnej LEX.

[19] Ustawa z dnia 10 kwietnia 2003 r. o szczególnych zasadach przygotowania i realizacji inwestycji w zakresie dróg publicznych (t. j. Dz.U. z 2017 r., poz.1496 ze zm.).

[20] Ustawa z dnia 14 czerwca 1960 r. - Kodeks postępowania administracyjnego (t.j. Dz. U. z 2017 r. poz. 1257 ze zm.).

[21] Ustawa z dnia 18 października 2006 r. o zmianie ustawy o szczególnych zasadach przygotowania $\mathrm{i}$ realizacji inwestycji w zakresie dróg krajowych oraz o zmianie niektórych innych ustaw (Dz. U z 2006 r., Nr 220, poz. 1601 ze zm.) oraz ustawa z dnia 25 lipca 2008 r. o zmianie ustawy o szczególnych zasadach przygotowania i realizacji inwestycji w zakresie dróg publicznych oraz o zmianie niektórych innych ustaw (Dz. U z 2008 r., Nr 154, poz. 958).

[22] Ustawa z dnia 21 sierpnia 1997 r. o gospodarce nieruchomościami (t.j. Dz. U. z 2018 r., poz. $121 \mathrm{ze} \mathrm{zm}$.).

[23] Ustawa z dnia 23 kwietnia 1964 r. - Kodeks cywilny (t. j. z 2018 r., poz. 1025).

[24] Ustawa z dnia 27 marca 2003 r. o planowaniu i zagospodarowaniu przestrzennym, (t. j. Dz. U. z 2017 r., poz. 1073 ze zm.).

[25] Ustawa z dnia 7 lipca 1994 r. Prawo budowlane (t. j. Dz. U. z 2017 r. poz. 1332 ze zm.).

[26] Wolanin M., Komentarz do ustawy o szczególnych zasadach przygotowania i realizacji inwestycji w zakresie dróg publicznych. C. H. Beck 2009, s. 33 i 190.

[27] Wolanin M., Wybrane problemy prawne zasad, formy i zakresu odszkodowania przy wywłaszczaniu praw rzeczowych, Palestra, 1995 r., nr 1-2, s. 50.

[28] Woś T., Wywłaszczenie nieruchomości i ich zwrot, LexisNexis 2011, s. 58-64 i 103104.

[29] Woś T., Wywłaszczenie nieruchomości i ich zwrot, LexisNexis 2011, s. 104-105.

[30] Woś T., Zezwolenie na realizację inwestycji drogowej w tzw. specustawie drogowej aspekty materialno prawne. w: Niewiadomski Z., Cieślak Z. (red.) Prawo do dobrej administracji. Materiały ze Zjazdu Katedr Prawa i Postępowania Administracyjnego, Warszawa-Dębe 23-25.IX.2002 r., Wydział Prawa Uniwersytetu Kardynała Stefana Wyszyńskiego, 2003, s. 381.

[31] www.temidium.pl/artykul/zezwolenie_na_realizacje_inwestycji_drogowej_wybrane_za gadnienia_na_tle_stosowania_ustawy_o_szczegolnych_zasadach_przygotowania_i_real i-4086.html, 15.06.2018 r.

[32] Wyrok Naczelnego Sądu Administracyjnego z dnia 14 listopada 2007 r., sygn. akt: I OSK 1485/06, System Informacji Prawnej LEX.

[33] Wyrok Naczelnego Sądu Administracyjnego z dnia 25 marca 2014 r., sygn. akt: I OSK 2090/12, System Informacji Prawnej LEX.

[34] Wyrok Naczelnego Sądu Administracyjnego z dnia 30 września 2016 r., sygn. akt: I OSK 1152/16, System Informacji Prawnej LEX.

[35] Wyrok Naczelnego Sądu Administracyjnego z dnia 4 października 2016 r., sygn. akt I OSK 2892/14, System Informacji Prawnej LEX.

[36] Wyrok Naczelnego Sądu Administracyjnego z dnia 9 grudnia 1998 r., sygn. akt: IV SA 2213/96, System Informacji Prawnej LEX.

[37] Wyrok Trybunału Konstytucyjnego z dnia16 października 2012 r., sygn. akt K 4/10, System Informacji Prawnej LEX .

[38] Wyrok Wojewódzkiego Sądu Administracyjnego w Warszawie z dnia 14 maja 2014 r., sygn. akt VIII SA/Wa 46/14, Na temat braku prawnej możliwości zrzeczenia się odszkodowania na gruncie specustawy drogowej System Informacji Prawnej LEX. 